\title{
PENGARUH KECAKAPAN PROFESIONAL, PENDIDIKAN BERKELANJUTAN DAN INDEPENDENSI PEMERIKSA TERHADAP KUALITAS HASIL PEMERIKSAAN
}

\author{
R. CINTA MARITO, EKA RIMA PRASETYA \\ Universitas Pamulang, Tangerang Selatan, Indonesia \\ *Email: ekhatyo11@gmail.com
}

\begin{abstract}
This study aims to determine the effect of Professional Skills, Continuing Education and the Examination Independence of the Quality of Examination Results.This type of research is a quantitative descriptive study that is used in the form of primary data collected from the results of the distribution of questionnaires to 45 auditor respondents at the Institute for Assessment and Application of Technology (BPPT) in Tangerang - Serpong. The sampling technique uses quota sampling technique. The data processing method uses multiple linear regression method using SPSS version 23.

The results showed that professional skills had a significant effect on the quality of examination results, continuing education had a significant effect on the quality of examination results, and the independence of examiners had a significant effect on the quality of examination results. Simultaneously professional skills, continuing education and the independence of examiners have a significant effect on the quality of examination results.
\end{abstract}

Keywords: Professional Skills, Continuing Education, Inspector Independence, Quality of Examination Results.

\section{PENDAHULUAN}

\section{Latar Belakang}

Setiap profesi harus mampu membangun kepercayaan masyarakat agar martabat dan kualitas jasa profesionalnya dapat terjaga. Untuk membangun kepercayaan masyarakat maka perilaku para profesional perlu diatur agar kualitas hasil pekerjaannya dapat dipertanggung jawabkan. Oleh karena itu dibutuhkan adanya standar dan aturan etika profesi agar masyarakat dapat meyakini kualitas pekerjaannya.

Kualitas dan kuantitas kinerja dalam profesi auditor tentunya hanya dapat diwujudkan oleh kinerja auditor dalam menjalankan tugasnya, sehingga dibutuhkan standar etika dan standar teknis sebagai dasar pelaksanaan tugas yang 
Jurnal Ilmiah Akuntansi Universitas Pamulang - Vol. 7, No. 2, Juli 2019 - Marito \& Prasetya

dipertanggung jawabkan pada auditor. Standar etika dapat berupa kode etik (code of ethics) atau kode (aturan) perilaku (code of conducts) profesi yang bersangkutan, sedangkan standar teknis merupakan standar pelaksanaan kegiatan audit tersebut yang berisi kriteria atau ukuran mutu minimal dalam kegiatan audit, Kusmanadji (2004:1-4). Setiap badan atau organisasi auditor harus memiliki standar audit dan standar etika yang wajib dipedomani oleh anggota profesinya dalam mewujudkan terciptanya audit yang kompeten. Sebagai tambahan, standar audit sektor publik secara garis besar mengacu pada Standar Profesional Akuntan Publik (SPAP) yang berlaku di Indonesia. Standar umum kedua (SA seksi 220 dalam SPAP, 2001) menyebutkan bahwa "dalam semua hal yang berhubungan dengan perikatan, independesi dalam sikap mental harus dipertahankan oleh auditor". Standar ini mengharuskan auditor untuk bersikap independen karena ia melaksanakan pekerjaan untuk kepentingan umum.

AAA Financial Accounting Standard Committee (2000) menyatakan bahwa :"Kualitas audit ditentukan oleh dua hal, yaitu kompetensi (keahlian) dan independensi, kedua hal tersebut berpengaruh langsung terhadap kualitas dan secara potensial saling mempengaruhi. Lebih lanjut, persepsi pengguna laporan keuangan atas kualitas audit merupakan fungsi dari persepsi mereka atas independensi dan keahlian auditor". Dari pengertian tentang kualitas audit tersebut, maka dapat disimpulkan bahwa kualitas audit merupakan segala kemungkinan dimana auditor pada saat mengaudit laporan keuangan klien dapat menemukan pelanggaran yang terjadi dalam sistem akuntansi klien dan melaporkannya dalam laporan keuangan auditan, dimana dalam melaksanakan tugasnya tersebut auditor berpedoman pada standar auditing dan kode etik akuntan publik yang relevan Tingginya harapan masyarakat akan terwujudnya good corporate governance dan penyelenggaraan organisasi sektor publik yang efektif, efisien, transparan, akuntabel serta bersih dan bebas dari praktik korupsi, kolusi, dan nepotisme membutuhkan peningkatan peran dari pengawasan internal. Dalam penyelenggaraanya good governance tidak hanya ditujukan bagi pemerintah pusat namun pemerintah daerah juga dituntut untuk melakukan good governance agar tercipta tata kelola pemerintahan yang baik di setiap lini pemerintahan.

\section{Rumusan Masalah}

Berdasarkan masalah dan studi konsumen, maka dapat dirumuskan sebagai berikut:

1. Apakah kecakapan profesional berpengaruh terhadap kualitas hasil pemeriksaan?

2. Apakah pendidikan berkelanjutan berpengaruh terhadap kualitas hasil pemeriksaan?

3. Apakah independensi pemeriksa berpengaruh terhadap kualitas hasil pemeriksaan?

4. Apakah kecakapan profesional, pendidikan berkelanjutan, dan independensi berpengaruh terhadap kualitas hasil pemeriksaan? 
Jurnal Ilmiah Akuntansi Universitas Pamulang - Vol. 7, No. 2, Juli 2019 - Marito \& Prasetya

\section{LANDASAN TEORI}

\section{Kualitas Hasil pemeriksaan}

Kualitas audit merupakan segala kemungkinan dimana auditor pada saat mengaudit laporan keuangan klien dapat menemukan pelanggaran yang terjadi dalam sistem akuntansi klien dan melaporkannya dalam laporan keuangan auditan, dimana dalam melaksanakan tugasnya tersebut auditor berpedoman pada standar auditing dan kode etik akuntan publik yang relevan. Kualitas audit dapat juga diartikan sebagai probabilitas seorang auditor dalam menentukan dan melaporkan penyelewengan yang terjadi dalam sistem akuntansi klien (Deangelo, 1981). Semakin tinggi kualitas audit dapat dihasilkan oleh auditor independen, maka semakin tinggi pula kepercayaan para pemakai informasi untuk menggunakan laporan keuangan.

Berdasarkan pengertian mengenai audit tersebut dapat kita simpulkan bahwasanya audit merupakan proses sistematik yang dilakukan oleh seorang yang independen dan kompeten dalam melakukan pemeriksaan dan memberikan opini terhadap kewajaran dari laporan audit tersebut.

\section{Kecakapan Profesional}

Kecakapan merupakan aspek intelektual yang berupa suatu kemampuan dalam mengenal, memahami, menganalisis, menilai dan memecahkan masalahmasalah dengan menggunakan rasio atau pemikiran. Menurut dirjen PLPS, Direktorat Tenaga Teknis, 2003, istilah kecakapan hidup life skills diartikan sebagai kecakapan atau kemampuan yang dimiliki seseorang untuk mau dan berani mengahadapi problema hidup dan penghidupan secara wajar tanpa merasa terkan, kemudian secara proaktif dan kreatif mencari serta menemukan solusi sehingga akhirnya mampu mengatasinya.

Menurut Martinis Yamin profesional adalah suatu pekerjaan yang membutuhkan pengetahuan ketrampilan, kemampuan, keahlian, dan ketelatenan untuk menciptakan anak memiliki perilaku sesuai yang diharapkan. Menurut dirjen PLPS, Direktorat Tenaga Teknis, 2003, istilah kecakapan hidup life skills diartikan sebagai kecakapan atau kemampuan yang dimiliki seseorang untuk mau dan berani mengahadapi problema hidup dan penghidupan secara wajar tanpa merasa terkan, kemudian secra proaktif dan kreatif mencari serta menemukan solusi sehingga akhirnya mampu mengatasinya.

Berdasarkan teori tersebut dapat disimpulkan Kecakapan profesional seorang Auditor harus memiliki keahlian khusus dan memilki pendidikan yang tinggi dan bertanggung jawab.

\section{Pendidikan Berkelanjutan}

Pendidikan berkelanjutan adalah kesempatan belajar bagi orang dewasa untuk meningkatkan kemampuan setelah mereka melakukan suatu pekerjaan atau suatu kegiatan sukarela di masyarakat. Pasal 18 UU RI tahun 2003, Opini atau Pendapat adalah perkiraan, pikiran, atau tanggapan tentang suatu hal (seperti orang atau peristiwa). Kemajuan di bidang teknologi dan informasi yang semakin 
Jurnal Ilmiah Akuntansi Universitas Pamulang - Vol. 7, No. 2, Juli 2019 - Marito \& Prasetya

cepat telah membawa perubahan yang fundamental dalam pengelolaan Sumber Daya Manusia. Arus informasi telah mampu merubah cara pandang dan cara berfikir manusia.

Tuntutan ini juga berpengaruh pada bidang audit internal yang semakin lama harus semakin meningkatkan mutu atau beberapa kriteria dari kecakapan teknis, mempunyai kesungguhan dan ketelitian kerja dalam profesinya, mengejar kepuasan orang lain, keberanian menaggung risiko, ketekunan dan ketabahan hati, integritas yang tinggi dan konsisten terhadap profesinya.

Pendidikan merupakan upaya untuk mengembangkan sumber daya manusia. Pelaksanaan pendidikan diarahkan kepada peningkatan keterampilan, pengetahuan serta perubahan sikap atau perilaku kerja karyawan.

\section{Independensi Pemeriksa}

Menurut Mulyadi (2002) mendefinisikan independensi adalah sikap mental yang bebas dari pengaruh, tidak dikendalikan oleh pihak lain, tidak tergantung pada orang lain. Menurut Halim (2008:46), independensi merupakan suatu cerminan sikap dari seorang auditor untuk tidak memilih pihak siapapun dalam melakukan audit. Menurut Siti (2009;51) independensi dapat dijabarkan sebagai cara pandang yang tidak memihak didalam pelaksanaan pengujian evaluasi hasil pemekriksaan dan penyusunan laporan audit.

\section{Kerangka Konseptual}

Kerangka pemikiran merupakan model konseptual tentang bagaimana teori berhubungan dengan berbagai faktor yang telah diidentifikasi sebagai masalah yang penting (Sugiyono, 2011:60).

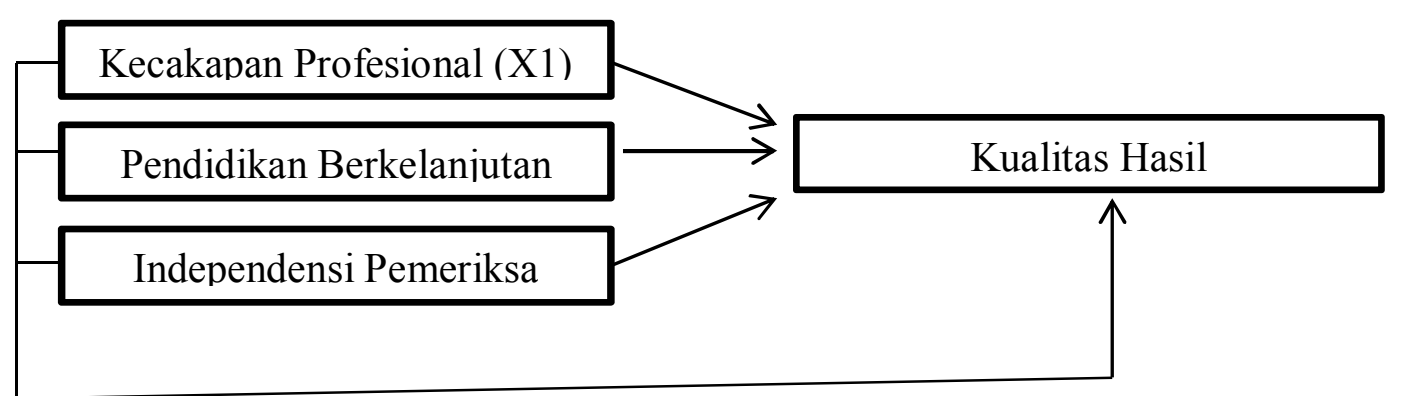

Gambar 3.1

Kerangka Konseptual

\section{METODE PENELITIAN}

\section{Jenis Penelitian}

Penelitian ini merupakan penelitian deskriptif kuantitatif dan desain penelitian korelasional. Berdasarkan informasi yang peneliti peroleh dari buku 
Jurnal Ilmiah Akuntansi Universitas Pamulang - Vol. 7, No. 2, Juli 2019 - Marito \& Prasetya

Metode Penelitian karangan Ronny Kountur (2004), maka maksud dari penelitian ini adalah untuk memberikan gambaran atau merupakan penelitian deskriptif (descriptive research). Penelitian deskriptif adalah jenis penelitian yang bertujuan untuk membuat suatu gambaran atau deskripsi mengenai fenomena sosial yang memiliki cirri-ciri seperti berhubungan dengan keadaan yang terjadi pada saat itu, mengurangi satu variabel saja atau beberapa variabel namun diuraikan satu persatu, dan variabel yang diteliti tidak dimanipulasi.

Adapun tujuan dari penelitian deskriptif ini untuk menyajikan secara sangat teliti (accurately and precisely) tentang karakteristik yang sangat luas dari suatu populasi yang mana hanya terbatas pada usaha mengungkapkan suatu masalah atau keadaan atau peristiwa sehingga bersifat sekedar untuk mengungkapkan fakta (fact finding). Dengan demikian hasil penelitian ditekankan untuk diteliti. Dalam hal ini menggambarkan Pengaruh Kecakapan profesional, Pendidikan berkelanjutan dan Independensi pemeriksa terhadap kualitas hasil pemeriksaan.

\section{Teknik Pengumpulan Data}

Metode pengumpulan data yang digunakan dalam penelitian ini adalah : Teknik Penyebaran Kuesioner (Angket). Kuesioner merupakan usaha untuk mengumpulkan informasi dengan menyampaikan sejumlah pertanyaan tertulis, untuk dijawab secara tertulis juga oleh responden. Teknik penyebaran kuesioner merupakan teknik pengumpulan data dengan memberikan atau menyebarkan sejumlah pertanyaan yang telah dirancang oleh peneliti sesuai dengan permasalahan penelitian kepada responden civitas akademik BPPT. Data yang dibutuhkan dalam penelitian ini diperoleh dari kuesioner yang dibagikan kepada responden yang berisikan sejumlah variabel yang ingin diteliti dalam penelitian ini. Penyebaran sejumlah pertanyaan dalam bentuk pertanyaan tertutup. Pertanyaan tertutup dimaksudkan agar responden tidak merasa terganggu kegiatannya dalam menjawab pertanyaan yang akan diajukan. Pertanyaan tertutup dimaksudkan agar responden tidak memerlukan waktu yang lama untuk memahami isi angket.

\section{Variabel dan Pengukuran}

Variabel adalah sesuatu yang menjadi pusat atau fokus perhatian, yang memberikan pengaruh dan memiliki nilai, sehingga dapat berubah.

Pada penelitian ini variable yang akan diteliti adalah :

Variabel dependen : Kualitas Hasil Pemeriksaan

Variabel independen : Kecakapan profesional, Pendidikan berkelanjutan, dan Independensi pemeriksaan

\section{Populasi dan Sampel}

Populasi adalah keseluruhan satuan analisis (unit of analysis) yang hendak diteliti, dalam hal ini adalah individu-individu responden. Definisi lain dari populasi atau universe adalah sejumlah keseluruhan dari unit analisa yang akan diduga. 
Jurnal Ilmiah Akuntansi Universitas Pamulang - Vol. 7, No. 2, Juli 2019 - Marito \& Prasetya

Dalam penelitian ini menggunakan teknik Quata Sampling yaitu menggunakan sampel unit populasi yang telah ditentukan lebih dulu, sehingga seluruh populasi yang termasuk dalam kuota haruslah dijadikan responden dalam penelitian tersebut. Jumlah pengambilan sampel dalam penelitian ini sebanyak 45 karyawan SPI BPPT.

\section{Teknik Analisis Data}

\section{Uji Kualitas Data}

Penelitian yang mengukur variabel dengan menggunakan instrumen kuesioner harus dilakukan pengujian kualitas terhadap data yang diperoleh. Pengujian ini bertujuan untuk mengetahui apakah instrumen yang digunakan valid dan reliable sebab kebenaran data yang diolah sangat menentukan kualitas hasil penelitian.

\section{Uji Validitas}

Uji validitas digunakan untuk mengukur sah atau valid tidaknya suatu kuesioner. Suatu kuesioner dikatakan valid jika pertanyaan pada kuesioner mampu untuk mengungkapkan sesuatu yang akan diukur oleh kuesioner tersebut. Pengujian validitas ini menggunakan Pearson Correlation yaitu dengan cara menghitung korelasi antara skor masing-masing butir pertanyaan dengan total skor. Jika angka korelasi yang diperoleh lebih besar dari angka kritik ( $\mathrm{r}$ hitung $>\mathrm{r}$ tabel) maka instrumen tersebut dikatakan valid.

2. Uji Reliabilitas

Uji reliabilitas dimaksudkan untuk mengetahui adanya tingkat keandalan alat ukur dalam penggunaannya atau dengan kata lain alat ukur tersebut memiliki hasil yang konsisten apabila digunakan berkali-kali. Besarnya koefisien alpha yang diperoleh menunjukkan koefisien reliabilitas instrumen. Reliabilitas instrument penelitian dalam penelitian ini diuji dengan menggunakan koefisien Cronbachs Alpha. Jika nilai koefisien alpha lebih besar dari 0,6 maka disimpulkan bahwa instrument penelitian tersebut handal atau reliabel (Nunnaly dalam Ghozali, 2005).

\section{Uji Normalitas}

Uji normalitas bertujuan untuk menguji apakah data telah memiliki distribusi normal. Pengujian ini dilakukan dengan menggunakan uji statistik nonparametik yaitu metode Kolmogrov-Smirnov. Pengambilan keputusan dilakukan dengan membandingkan $p$ value yang diperoleh dari hasil pengujian normalitas. Data dikatakan terdisribusi secara normal jika $p$ value $>$ a) 0.05 , begitu juga sebaliknya.

4. Uji Heteroskedastisitas

Uji Heteroskedastisitas bertujuan untuk menguji apakah dalam model regresi terjadi ketidaksamaan variance dari residual satu pengamatan ke pengamatan lain, Ghozali dalam Arini (2010:81). Jenis uji yang digunakan adalah uji glejser dengan meregresi nilai absolut residual terhadap variabel independen. Apabila probabilitas signifikansi diatas $5 \%$ atau 0,05 maka model regresi tidak mengandung adanya heteroskedastisitas. 
Jurnal Ilmiah Akuntansi Universitas Pamulang - Vol. 7, No. 2, Juli 2019 - Marito \& Prasetya

5. Uji Multikolinieritas

Dalam penelitian ini, uji asumsi klasik yang akan dilakukan adalah multikolinieritas. Interpretasi dari persamaan regresi tidak tepat bila variabelvariabel bebas dalam model penelitian memiliki hubungan linier. Multikolinieritas dapat di deteksi dengan melihat nilai R2 dimana dikatakan terdapat multikolinieritas bilai nilai R2 yang dihasilkan dari suatu model terlalu tinggi namun tidak banyak variabel bebas yang mempengaruhi variabel terikat. Selain itu, multikolinieritas juga dapat diketahui dengan melihat korelasi antar variabel bebas dalam matriks korelasi dan bila nilai korelasinya melebihi $80 \%$ maka terdapat multikolinieritas antar dua variabel bebas tersebut.

6. Uji Regresi Linear Berganda

Setelah dilakukannya uji asumsi klasik (normalitas, multikolinieritas, dan heteroskedastisitas) dan memperoleh hasil yang wajar (qualified), maka analisis regresi dapat dilaksanakan.

Berhubungan dengan variabel independen dalam penelitian ini lebih dari satu, maka jenis analisis yang digunakan yaitu analisis regresi berganda, dimana diperuntukkan untuk mengetahui seberapa besar pengaruh variabel independen (lebih dari satu) dengan variabel dependennya.

Dengan demikian, model persamaan regresi linear berganda menjadi :

$\mathrm{Y}=\alpha+\beta 1 \mathrm{X} 1+\beta 2 \mathrm{X} 2+\beta 3 \mathrm{X} 3+\mathrm{e}$

Keterangan:

$\mathrm{Y}=$ Kualitas hasil pemeriksaan

$\mathrm{X} 1=$ Kecakapan profesional

$\mathrm{X} 2=$ Pendidikan berkelanjutan

$\mathrm{X} 3=$ Independensi pemeriksa

$\beta 1=$ Koefisien regresi X1

$\beta 2=$ Koefisien regresi $\mathrm{X} 2$

$\beta 3=$ Koefisien regresi $\mathrm{X} 3$

$\alpha=$ konstanta

$\mathrm{e}=$ eror time

7. Uji Koefisien Determinasi

Untuk menilai seberapa besar pengaruh variabel $\mathrm{X}$ terhadap $\mathrm{Y}$, peneliti menggunakan koefisien determinasi $(\mathrm{Kd})$ yang dapat dinyatakan dalam bentuk persantase sebagaii hasil dari rumusan berikut :

$\mathrm{Kd}=(\mathrm{rs})^{2} \times 100 \%$

Keterangan :

Kd : Koefisien Determinasi

rs : Koefisien rank spearman

8. Uji Koefisien Korelasi

Dalam menilai kekuatan/korelasi dari hubugan yang dimiliki antar variabel tersebut. 
Jurnal Ilmiah Akuntansi Universitas Pamulang - Vol. 7, No. 2, Juli 2019 - Marito \& Prasetya

\section{Uji Hipotesis}

Uji Signifikansi Parsial ( Uji-t)

Uji t dalam penelitian ini diuji dengan menggunakan analisis regresi linear yaitu analisis yang digunakan untuk mengetahui sejauh mana pengaruh kecakapan profesional, pendidikan berkelanjutan dan independensi pemeriksa sebagai variabel independen terhadap kualitas hasil pemeriksaan sebagai variabel dependen. Untuk mengetahui pengaruh variabel independen (kecakapan profesional, pendidikan berkelanjutan dan independensi pemeriksa) terhadap variabel dependen (kualitas hasil pemeriksaan), maka dilakukan dua cara, yaitu: uji secara parsial dan uji secara simultan.

Uji t Parsial dalam analisis regresi bertujuan untuk mengetahui apakah variabel bebas $(\mathrm{X})$ secara parsial (sendiri) berpengaruh signifikan terhadap variabel (Y).

Berdasarkan nilai t hitung dan $\mathrm{t}$ table, adalah :

1. Jika nilai $t$ hitung $>t$ tabel maka variabel bebas berpengaruh terhadap variabel terikat.

2. Jika nilai $\mathrm{t}$ hitung $<\mathrm{t}$ tabel maka variabel bebas tidak berpengaruh terhadap variabel terikat.

Berdasarkan nilai signifikasi hasil output SPSS

1. Jika nilai $\mathrm{Sig},<0,05$ maka variabel bebas berpengaruh signifikan terhadap variabel terikat.

2. Jika nilai Sig. $>0,05$ maka variabel bebas tidak berpengaruh signifikan terhadap variabel terikat.

\section{Uji Simultan (Uji F)}

Uji F Statistik digunkan untuk mengetahui apakah variabel independen Kecakapan profesional (X1), Pendidikan berkelanjutan (X2), dan Independensi pemeriksa (X3) secara parsial berdampak terhadap variabel dependen Kualitas hasil pemeriksaan (Y). Rumus Uji F seperti yang dikemukakan oleh Sugiyono (2011: 47) sebagai berikut :

Keterangan:

$\mathrm{N}$ = banyak sampel

$\mathrm{m}=$ banyak prediktor

$\mathrm{R}=$ koefisien korelasi antara kriterium dengan prediktor.

Penggunaan tingkat signifikansinya beragam, tergantung keinginan peneliti, yaitu $0,01(1 \%) ; 0,05(5 \%)$ dan $0,10(10 \%)$.

Hasil uji F dilihat dalam tabel ANOVA dalam kolom sig. Sebagai contoh, kita menggunakan taraf signifikansi $5 \%(0,05)$, jika nilai probabilitas $<0,05$, maka dapat dikatakan terdapat pengaruh yang signifikan secara bersama-sama antara variabel bebas terhadap variabel terikat.

Namun, jika nilai signifikansi $>0,05$ maka tidak terdapat pengaruh yang signifikan secara bersama-sama antara variabel bebas terhadap variabel terikat. 
Jurnal Ilmiah Akuntansi Universitas Pamulang - Vol. 7, No. 2, Juli 2019 - Marito \& Prasetya

\section{HASIL DAN PEMBAHASAN}

\section{Uji Kualias Data \\ Uji Validitas}

Selanjutnya dilakukan uji validitas (keabsahan) dan reliabilitas (keandalan) dari alat ukur yang digunakan dalam penelitian ini, untuk memastikan bahwa seluruh item pernyataan yang digunakan dalam penelitian ini memiliki konsistensi internal untuk mengukur aspek yang sama dalam kuisioner.

Pengujian validitas dilakukan pada penelitian ini menggunakan Metode corrected item-total correlation dengan cara mengkorelasikan masing-masing skor total item dan melakukan joreksi terhadap nilai koefisien korelasi yang overestimasi (estimasi nilai lebih tinggi dengan sebenarnya).

\section{Uji Reliabilitas}

Uji reliabilitas (keandalan) juga dilakukan item-item pernyataan dan indikator yang dinyatakan valid diukur reliabilitasnya atau keandalannya dengan bantuan program SPSS ver. 23.0 for Windows. Begitu pula pendapat secara teori menurut Priyatno (2011:69) Untuk menentukan apakah instrumen tersebut reliable atau tidak, bisa digunakan batasan tertentu seperti 0,6. Reabilitas apabila kurang dari 0,6 adalah kurang baik, sedangkan 0,7 dapat diterima dan diatas 0,8 adalah baik.

Hasil pengukuran reliabilitas ditunjukkan pada tebel dibawah ini. Berdasarkan perhitungan dengan olahan data statistik SPSS yang terlihat pada lampiran, diperoleh hasil -hasil reliabilitas untuk masing-masing variabel sebagai berikut :

\section{Tabel 1}

Uji Reliabilitas

\begin{tabular}{|l|l|l|l|l|}
\hline No. & Variabel & $\begin{array}{l}\text { Cronbach's } \\
\text { Alpha }\end{array}$ & rkritis & ket \\
\hline 1 & Kecakapan Profesional & 0.908 & 0,60 & Reliabel \\
\hline 2 & $\begin{array}{l}\text { Pendidikan } \\
\text { berkelanjutan }\end{array}$ & 0.876 & 0,60 & Reliabel \\
\hline 3 & Independensi pemeriksa & 0.888 & 0,60 & Reliabel \\
\hline 4 & $\begin{array}{l}\text { Kualitas hasil } \\
\text { pemeriksaan }\end{array}$ & 0.956 & 0,60 & Reliabel \\
\hline
\end{tabular}

Sumber: Data Diolah Penulis, 2017

Nilai Cronbach's Alpha yang diperoleh adalah variable Kecakapan Profesional menunjukkan ralpa 0,908, variabel Pendidikan berkelanjutan menunjukkan ralpa 0,876 , variabel Independensi pemeriksa menunjukkan ralpa 0,888 dan variabel Kualitas hasil pemeriksaan menunjukkan ralpa 0,56. Dengan demikian karena nilai ini lebih besar dari batasan 0,60 , maka ketiga variabel ini dapat dinyatakan reliabel. 
Jurnal Ilmiah Akuntansi Universitas Pamulang - Vol. 7, No. 2, Juli 2019 - Marito \& Prasetya

\section{Uji Regresi Berganda}

Menurut (Priyatno, 2011:238) analisis regresi linier berganda digunakan untuk mengetahui pengaruh antara dua variabel atau lebih variabel independen dan satu variabel dependen yang ditampilkan dalam bentuk persamaan regresi. Variabel independen dilambangkan dengan X1, X2, X3 .... Xn sedangkan variabel dependen dilambangkan dengan Y. Pada tabel dibawah ini adalah hasil analisis regresi linier berganda.

Tabel 2

Uji Regresi Berganda

\begin{tabular}{|l|l|l|l|l|l|}
\hline \multirow{2}{*}{ Model } & \multicolumn{2}{l|}{$\begin{array}{l}\text { Unstandardized } \\
\text { Coefficients }\end{array}$} & $\begin{array}{l}\text { Standardized } \\
\text { Coefficients }\end{array}$ & T & \multirow{2}{*}{ Sig. } \\
\cline { 2 - 5 } & $\mathrm{B}$ & Std. Error & Beta & & \\
\hline 1 (Constant) & 4.074 & 2.121 & & 1.921 & .063 \\
Kecakapan Profesional & .956 & .251 & .288 & 3.810 & .001 \\
Pendidikan berkelanjutan & 1.333 & .280 & .411 & 4.769 & .000 \\
Independensi pemeriksa & 1.044 & .266 & .315 & 3.928 & .000 \\
\hline
\end{tabular}

Sumber : Data Diolah Penulis, 2017.

Untuk membuat persamaan garis regresi dapat dilihat dari kolom B.

Constant $=4.074$

Kecakapan Profesional $=0.956$

Pendidikan Berkelajutan $=1.333$

Independensi Pemeriksa $=1.044$

Berarti persamaan garisnya adalah :

$\mathrm{Y}=4.074+0.956 \mathrm{X} 1+1.333 \mathrm{X} 2+1.044 \mathrm{X} 3$

1) Konstanta sebesar 4.074 menyatakan bahwa jika tidak ada Kecakapan Profesional, Pendidikan berkelanjutan dan Independensi Pemeriksa maka pengaruh terhadap Kualitas hasil pemeriksaan adalah sebesar 4.074.

2) Koefisien $\mathrm{X} 1=0.956$, menunjukkan bahwa Kecakapan Profesional (X1) berpengaruh terhadap Kualitas hasil pemeriksaan (Y). Artinya, jika Kecakapan Profesional ditingkatkan sebesar satu satuan, maka peningkatan Kualitas hasil pemeriksaan akan meningkat sebesar 0.956 .

3) Koefisien $\mathrm{X} 2=1.333$, menunjukkan bahwa Pendidikan berkelanjutan (X2) berpengaruh terhadap Kualitas hasil pemeriksa (Y). Artinya, jika Pendidikan berkelanjutan ditingkatkan sebesar satu satuan, maka peningkatan Kualitas hasil pemeriksa akan meningkat sebesar 1.333.

4) Koefisien $\mathrm{X} 3=1.044$, menunjukkan bahwa Independensi pemeriksa (X3) berpengaruh terhadap Kualitas hasil pemeriksaan (Y). Artinya, jika Independensi Pemeriksa ditingkatkan sebesar satu satuan, maka peningkatan Kualitas hasil pemeriksaan akan meningkat sebesar 1.044.

5) Standar error (e) menunjukkan tingkat kesalahan pengganggu.

6) Hasil regresi linier ganda di atas menunjukkan bahwa variabel Kecakapan Profesional, Pendidikan berkelanjutan dan Indpendensi pemeriksa memiliki pengaruh terhadap variabel Kualitas hasil pemeriksaan. Dengan demikian 
Jurnal Ilmiah Akuntansi Universitas Pamulang - Vol. 7, No. 2, Juli 2019 - Marito \& Prasetya

dapat ditarik kesimpulan bahwa, jika Kecakapan Profesional, Pendidikan berkelanjutan dan Independensi Pemeriksa ditingkatkan maka Kualitas hasil pemeriksaan juga akan meningkat.

\section{Koefisien Korelasi}

Analisis korelasi ini digunakan untuk mengetahui tingkat (derajat) keeratan hubungan antara variabel bebas dengan variabel terikat, semakin besar korelasi maka semakin kuat hubungannya.

Berikut ini adalah hasil perhitungan analisis korelasi Kecakapan Profeional, Pendidikan berkelanjutan, dan Independensi pemeriksa terhadap Kualitas hasil pemeriksaan yang telah di analisis menggunakan bantuan program SPSS 23.00 adalah sebagai berikut :

Tabel 3

Hasil Uji Koefisien Korelasi Model Summaryb

\begin{tabular}{|l|l|l|l|l|l|}
\hline Model & R & R Square & $\begin{array}{l}\text { Adjusted R } \\
\text { Square }\end{array}$ & $\begin{array}{l}\text { Std. Error } \\
\text { of the } \\
\text { Estimate }\end{array}$ & $\begin{array}{l}\text { Durbin- } \\
\text { Watson }\end{array}$ \\
\hline 1 & $.971 \mathrm{a}$ & .956 & .954 & 1.990 & 2.009 \\
\hline
\end{tabular}

a. Predictors: (Constant), Kecakapan Profesional, Pendidikan

berkelanjutan, Independensi Pemeriksa

b. Dependent Variable: Kualitas hasil pemeriksaan

Sumber : Data Diolah Penulis, 2017.

Dengan melihat dari tabel diatas hasil perhitungan diatas nilai $\mathrm{R}$ sebesar 0,971. Interpretasi hasil nilai memenuhi range $0,80-1,00=$ Sangat Kuat. Hal ini menunjukkan bahwa antar variabel Kecakapan Profesional, Pendidikan berkelanjutan dan Independensi pemeriksa terhadap Kualitas hasil pemeriksaan memiliki hubungan yang sangat kuat atau berkorelasi.

Sehingga baik atau buruknya kualitas hasil pemeriksaan tidak terlepas dari pengaruh Kecakapan Profesional, Pendidikan berkelanjutan dan Independensi pemeriksa yang dimiliki oleh auditor tersebut.

\section{Koefisien Determinasi}

Menurut Priyatno (2011:251) Analisis determinasi digunakan untuk mengetahui presentase sumbangan pengaruh variabel independen secara bersamasama terhadap variabel dependen. Hasil analisis determinasi dapat dilihat pada output model Model Summary dari hasil analisis regresi linier berganda. Untuk pengukuran digunakan Adjusted R2 sebagai koefisien determinasi.

Uji ini bertujuan untuk mengukur seberapa besar variasi dari variabel independen dapat menjelaskan variabel dependen. Kelemahan mendasar penggunaan koefisien determinasi adalah bias terhadap jumlah variabel independen yang dimasukkan kedalam model. Banyak peneliti menganjurkan untuk menggunakan nilai Adjusted $\mathrm{R}^{2}$ pada saat mengevaluasi mana model regresi terbaik karena nilai 
Jurnal Ilmiah Akuntansi Universitas Pamulang - Vol. 7, No. 2, Juli 2019 - Marito \& Prasetya

Adjusted $\mathrm{R}^{2}$ dapat naik atau turun apabila suatu variabel independen ditambahkan kedalam model. Hasil uji koefisien determinasi dapat dilihat pada tabel berikut ini:

Tabel 4

Hasil Uji Koefisien Determinasi

\begin{tabular}{|l|l|l|l|l|l|}
\hline Model & R & R Square & $\begin{array}{l}\text { Adjusted R } \\
\text { Square }\end{array}$ & $\begin{array}{l}\text { Std. Error of } \\
\text { the Estimate }\end{array}$ & $\begin{array}{l}\text { Durbin- } \\
\text { Watson }\end{array}$ \\
\hline 1 & $.971 \mathrm{a}$ & .956 & .954 & 1.990 & 2.009 \\
\hline
\end{tabular}

a. Predictors: (Constant), Kecakapan Profesional, Pendidikan berkelanjutan Independensi pemeriksa

Sumber : Data Diolah Penulis, 2017.

Dengan melihat dari tabel diatas hasil perhitungan di atas di mana Adjusted R Square sebesar 0,954 atau 95,4\%. Hal ini menunjukkan besarnya kontribusi dari Kecakapan Profesional, Pendidikan berkelanjutan dan Independensi pemeriksa terhadap Kualitas hasil pemeriksaan sebesar $95.4 \%$ sedangkan sisanya $4.6 \%$ merupakan kontribusi faktor lain yang tidak diteliti dalam penelitian ini.

\section{Uji Hipotesis Parsial (Uji t)}

Menurut Priyatno (2011:258) uji t digunakan untuk mengetahui pengaruh masing-masing variabel independen terhadap variabel dependen. Kriteria pengambilan adalah bila tingkat signifikan $<0.05$ maka Ho ditolak dan menerima H1. Langkah-langkah pengujiannya adalah sebagai berikut :

1. Merumuskan Hipotesis

$\mathrm{H} 0$ : artinya tidak terdapat pengaruh

$\mathrm{H} 1$ : artinya ada pengaruh

2. Menentukan tingkat signifikansi yang digunakan yaitu 0,05 .

3. Kriteria pengambilan keputusan untuk hipotesis yang diajukan adalah jika Sig. $<0,05$ maka H0 ditolak. Jika Sig. $>0,05$ maka H0 diterima.

Hasil uji t pada penelitian ini dapat dilihat ditabel berikut ini :

\section{Tabel 5}

Hasil Uji Parsial (Uji t) Coefficients

\begin{tabular}{|l|l|l|l|l|l|}
\hline \multirow{2}{*}{ Model } & \multicolumn{2}{l|}{$\begin{array}{l}\text { Unstandardized } \\
\text { Coefficients }\end{array}$} & $\begin{array}{l}\text { Standardized } \\
\text { Coefficients }\end{array}$ & \multirow{2}{*}{ T } & \\
\cline { 2 - 5 } & $\mathrm{B}$ & Std. Error & Beta & & \\
\hline 1 (Constant) & 4.074 & 2.121 & & 1.921 & .063 \\
Kecakapan Profesional & .956 & .251 & .288 & 3.810 & .001 \\
Pendidikan berkelanjutan & 1.333 & .280 & .411 & 4.769 & .000 \\
Independensi pemeriksa & 1.044 & .266 & .315 & 3.928 & .000 \\
\hline
\end{tabular}

Sumber : Data Diolah Penulis, 2017.

Berdasarkan tabel diatas, maka hasil uji t pada penelitian ini dapat dijelaskan sebagai berikut :

1. Variabel (X1) Kecakapan Profesional 
Jurnal Ilmiah Akuntansi Universitas Pamulang - Vol. 7, No. 2, Juli 2019 - Marito \& Prasetya

Pada variable Kecakapan Profesional dengan tingkat signifikansi 95\% ( $\alpha$ $=0,05)$. Angka signifikansi (P Value) pada variabel Kecakapan Profesional sebesar $0,001<0,05$. Atas dasar perbandingan tersebut, maka $\mathrm{H} 0$ ditolak dan H1 diterima atau berarti Kecakapan Profesional mempunyai pengaruh yang signifikan terhadap Kualitas hasil pemeriksa. Hipotesis pertama (H1) yang diujikan yang menyatakan bahwa Kecakapan Profesional berpengaruh positif signifikan terhadap kualitas hasil pemeriksaan diterima.

2. Variabel (X2) Pendidikan Berkelanjutan

Pada variabel Pendidikan berkelanjutan dengan tingkat signifikansi 95\% ( $\alpha$ $=0,05$ ). Angka signifikansi ( $P$ Value) pada Pendidikan berkelanjutan sebesar $0,000<0,05$. Atas dasar perbandingan tersebut, maka H0 ditolak dan H1 diterima atau berarti variabel Pendidikan berkelanjutan mempunyai pengaruh positif signifikan terhadap Kualitas hasil pemeriksa. Hipotesis kedua (H2) yang diujikan yang menyatakan bahwa Pendidikan berkelanjutan berpengaruh positif signifikan terhadap kualitas pemeriksaan diterima.

3. Variabel (X3) Independensi Pemeriksa

Pada variable Independensi pemeriksa dengan tingkat signifikansi 95\% ( $\alpha$ $=0,05)$. Angka signifikansi $(P$ Value $)$ pada Independensi pemeriksa sebesar $0,000<0,05$. Atas dasar perbandingan tersebut, maka $\mathrm{H} 0$ ditolak dan $\mathrm{H} 1$ diterima atau berarti variable Independensi pemeriksa mempunyai pengaruh yang signifikan terhadap Kualitas hasil pemeriksaan. Hipotesis ketiga (H3) yang diujikan yang menyatakan bahwa Independensi pemeriksa berpengaruh positif signifikan terhadap kualitas hasil pemeriksaan diterima.

\section{Uji Hipotesis Simultan (Uji F)}

Menurut (Priyatno, 2011:258) uji F digunakan untuk menguji pengaruh semua variabel independen atau variabel bebas secara bersama-sama terhadap variabel dependen atau variabel terikat. Kriteria pengambilan keputusannya adalah bila F Sig. $<0.05$ maka Ho ditolak dan menerima H1. Hasil uji F dalam penelitian ini dapat dilihat pada tabel berikut ini :

\section{Tabel 6}

Uji (F) Secara Simultan

\begin{tabular}{|l|l|l|l|l|l|}
\hline Model & $\begin{array}{l}\text { Sum of } \\
\text { Squares }\end{array}$ & Df & $\begin{array}{l}\text { Mean } \\
\text { Square }\end{array}$ & F & Sig. \\
\hline 1 & 4822.995 & 3 & 1607.665 & 405.847 & .000 \\
$\begin{array}{c}\text { Regression } \\
\begin{array}{l}\text { Residual } \\
\text { Total }\end{array}\end{array}$ & $\begin{array}{l}142.605 \\
4965.600\end{array}$ & 36 & 3.961 & & \\
\hline
\end{tabular}

a. Dependent Variable: Kualitas hasil pemeriksaan

b. Predictors: (Constant), Kecakapan profesional, Pendidikan berkelanjutan,Independensi pemeriksa

Sumber : Data Diolah Penulis, 2017.

Berdasarkan data tabel diatas terlihat bahwa nilai $\mathrm{F}$ berada pada signifikansi 0,000 yang berarti $<0,05$. Dengan demikian secara bersama-sama Kecakapan profesional, Pendidikan berkelanjutan, dan Independensi pemeriksa berpengaruh nyata terhadap Kualitas hasil pemeriksaan. Hipotesis keempat $(\mathrm{H} 4)$ yang diujikan

* Corresponding author's e-mail: ekhatyo11@gmail.com 
Jurnal Ilmiah Akuntansi Universitas Pamulang - Vol. 7, No. 2, Juli 2019 - Marito \& Prasetya

yang menyatakan bahwa Kecakpan professional, Pendidikan berkelanjutan dan Independensi pemeriksa berpengaruh dan nyata terhadap Kualitas hasil pemeriksaan dapat diterima.

\section{KESIMPULAN}

Berdasarkan hasil penelitian yang telah dilakukan di Badan Pengkajian dan Penerapan Teknologi (BPPT), dengan rentang tanggal periode 24 Juli 2017 sampai dengan tanggal 31 Agustus 2017, maka dapat disimpulkan bahwa :

1. Kecakapan profesional berpengaruh signifikan terhadap kualitas hasil pemeriksaan.

2. Pendidikan berkelanjutan berpengaruh signifikan terhadap kualitas hasil pemeriksaan.

3. Independensi Pemeriksa berpengaruh signifikan terhadap kualitas hasil pemeriksaan.

4. Kecakapan Profesional, Pendidikan berkelanjutan dan Independensi pemeriksa berpengaruh signifikan terhadap kualitas hasil pemeriksaan.

\section{DAFTAR PUSTAKA}

AAA Committee,(2000). Financial Accounting Standard Commentary: SEC. Auditor Independence Requirements. Accounting Horizons

De Angelo, (1981). University of Pennsylvania, Philadelphia, PA 19104, USA. Received May 1981, final version received July 1981. Journal of Accounting and Economis.

Donal halim, (2008). Auditing (Dasar- dasar Audit Llaporan Keuangan). Yogyakarta: Unit penerbit dan percetakan STIM YKPN.

Kusmanadji, (2004) Pengaruh Penerapan Kode Etik APIP terhadap kinerja auditor pemerintah badan pengawasan keuangan dan pembangunan (BPKP) Makassar Sulawesi Selatan

Mulyadi (2002) Auditing, Buku Dua, Edisi ke enam, Salemba Empat. Jakarta.

Ronny Kountur, (2004). Metode Penelitian dan Teori Komunikasi: Pendekatan Praktis. Penulisan Proposal dan Laporan Penelitian. Malang: UMM Press.

Sugiyono, (2011). Metode Penelitian Kuantitatif Kualitatif dan R\&D. Alfabeta. Yudha M. Saputra (2008). perkembangan dan belajar motorik . redpoint. Laksona dkk.

* Corresponding author's e-mail: ekhatyo11@gmail.com 